Island Studies Journal, Vol. 4, No. 2, 2009, pp. 225-240

\title{
Tourism Changes on a Mediterranean Island: Experiences from Mallorca
}

\author{
Stephen A. Royle \\ Queen's University Belfast \\ Northern Ireland, United Kingdom \\ s.royle@qub.ac.uk
}

\begin{abstract}
Mediterranean islands exemplify well the interactions between tourism, heritage and culture on islands. After an introduction that considers their heritage and the pressures which might be applied by tourism because of insular characteristics such as scale, the paper considers the Spanish island of Mallorca as a case study. First its history and consequent heritage is identified and then various stages in its tourism development, which might be recognized in Butler's model, are treated with particular reference to two very different foreigner commentators on the island, George Sand and Robert Trimnell. The mass market tourism exemplified by Trimnell has brought a reaction and in recent decades Mallorca has given much more consideration to its environment and heritage, illustrated here through the example of the district of Calvià and its Local Agenda 21 policies. This has seen a considerable impact on the island's tourism and marketing initiatives, as well as upon its natural environment.
\end{abstract}

Keywords: Calvià, culture, George Sand, heritage, islands, Local Agenda 21, Mallorca, Mediterranean islands, Richard Butler, Robert Trimnell, tourism.

(C) 2009 - Institute of Island Studies, University of Prince Edward Island, Canada

\section{Introduction}

The Mediterranean littoral has been the locus of competing civilizations of the classical world; the rich heritage which has resulted is shared with its islands. In fact, some islands have a wider heritage footprint than most mainland areas since, if they had a strategic location, they might frequently be contested between different powers and as a result display souvenirs from several civilizations. These struggles continued from classical times, through the disputes between Christians and Muslims in the medieval and early modern periods, into the colonial era and the $20^{\text {th }}$ century: some Mediterranean islands were significant stages for action in World War II as with the Battle of Crete in 1941 when Germany took the island after an invasion by parachutists and held it for four years (Forty, 2001). A smaller case is the Greek island of Syros, one of the Cyclades, which was subject to devastation and famine in 1941 after the Italian invasion (Lecouer, 2008). Another example is Malta, already replete with conflict-related heritage from and after the Great Siege of 1565 (Bradford, 1999), which was awarded the George Cross in 1942 after its resistance to the German siege (e.g. Oliver, 1942). Sites associated with that conflict (such as the ruined Opera House just inside the walls of Valletta) have cultural meaning for the islanders. Further east, Cyprus displays a varied legacy from its complex political history, especially the competing Greek- and Turkish-related population groups. This island was invaded from Turkey in 1974 and, although the wounds from this as-yet-unresolved 
situation (Bartlett, 2007) are still raw, publications have already identified the resultant cultural heritage (Jansen, 2005).

Such legacies, in both physical and cultural terms, might be at risk in the restricted ecumene of the island setting, especially from large-scale tourism, an economic activity adopted by many of them, which is particularly demanding upon land and the environment. Islands are bounded places, often without substantial frontier or wilderness regions and may well be forced to re-use and recycle areas more than might be necessary in continental locations, with a potential for conflict arising as a result from the sacrifice of cherished open space or other pre-existing land uses, some of which may have cultural meaning. Island cultures, expressed through distinctive language and/or other manifestations, might also be at risk from a tide of visitors, many of whom might not choose to conform to local norms.

The author has recently written about island tourism, making the distinction between 'mainland' and 'entry' islands (Royle, 2008), not dissimilar to the 'nodal' or 'cross-roads' islands versus the 'isolated' islands of Connell and King (1999: 3). 'Entry' islands are those that only in recent years have begun seeking to obtain a share of global tourism. They are usually remote and able to offer niche attractions to only a limited potential clientele, which chooses especially to travel to that location. Examples discussed were the Falkland Islands with their wildlife; St Helena with its Napoleonic legacy and Easter Island (Rapa Nui) with its moai statues. 'Mainland' islands were defined as those located within easy reach of major tourist demand and where, given that most of the tourists arrive by air or cruise ship, functionally their tourism trade is little different from coastal mainland resort areas in the same region. Examples would be parts of the Caribbean island realm viz a viz Mexico and, in the Mediterranean, the Balearic Islands compared to the mainland Spanish costas. These 'mainland'-style tourist islands are usually heavily engaged in mass tourism with all its potential pressures on land-use, culture and heritage. Mallorca, the case-study island considered below, is a prime example.

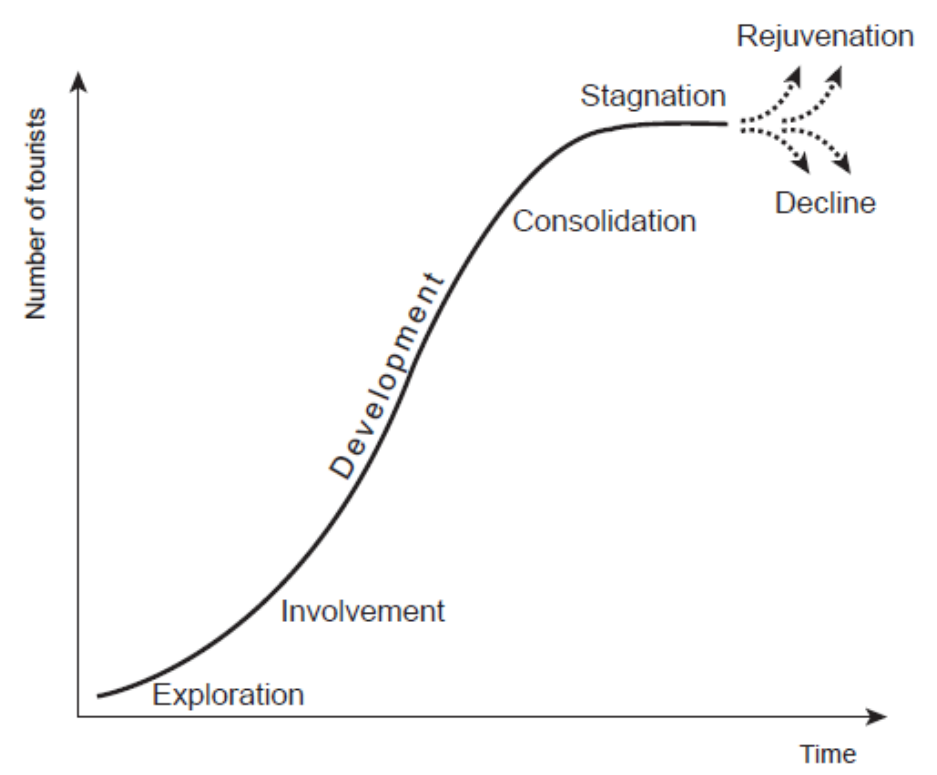

This study of Mallorca's tourism is set within the framework of Richard Butler's (1980, 2003) tourist area cycle of evolution (Figure 1).

Figure 1 - Butler's Tourism model.

Source: Redrawn from Butler (1980). 
One question to be considered below is how closely the island follows the Butler model, especially in its later stages. Butler's initial, common, stages are entitled successively 'exploration', 'involvement', 'development', 'consolidation' and 'stagnation'. This article will show from the writings of outsiders how Mallorca progressed through such stages to reach its position as a mass-market destination by the late $20^{\text {th }}$ century. Obviously, there is an issue about these outsiders failing to develop full comprehension of the islanders' own attitudes to Mallorca, but to use the work of foreigners here is a valid approach in that the island's tourism development depended largely on the perceptions of outsiders. The author, too, is an outsider, if one with the experience of visiting Mallorca on almost annual field trips with geography students over more than a quarter of a century. At Butler's 'stagnation' stage, the consequences of mass tourism had begun to engender environmental, cultural and heritage concerns on Mallorca and these will be seen here, reflected in the local press, including that published in the foreign languages of the tourists. Butler's model follows 'stagnation' with either 'rejuvenation' or 'decline'. Regarding Mallorca, rejuvenation was the path adopted, with a refocus of tourism away from the cheap and cheerful mass-market to encompass also wealthier and more environmentallyand culturally-aware clients. A further catalyst for this change was the opportunities, indeed obligations, provided by the strictures of Local Agenda 21 after the Rio de Janeiro Earth Summit of 1992, a programme that was adopted more widely in Spain than in many other European countries (Garcia-Sanchez \& Prado-Lorenzo, 2008).

\section{Mallorca}

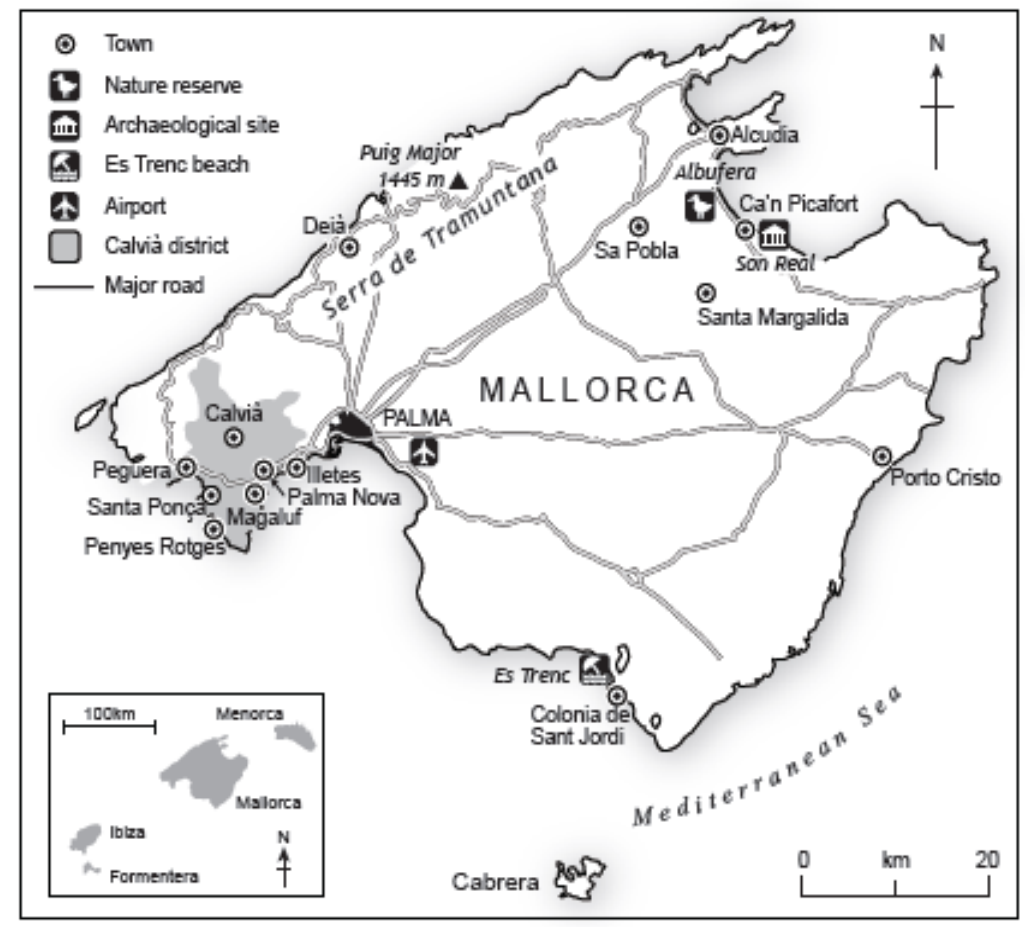

Figure 2 - Mallorca and the Balearic Islands (inset).
At $3,640 \mathrm{~km}^{2}$ Mallorca (sometimes Majorca) (Figure 2) is the largest of the four Balearic Islands (Illes Balears in the local language; the others are Menorca, Ibiza (Eivissa) and Formentera, the smallest). As well as being one of Spain's 50 provinces, the archipelago forms one of the country's 17

Autonomous Communities, which gives its government considerable power over local affairs. 
The capital city is Mallorca's principle settlement of Palma de Mallorca (usually just called by its local name of Palma). The locals speak Mallorcan (Mallorqui), a dialect of Catalan, although Castilian Spanish is universally understood and both are official languages.

Mallorca's population was 814,775 in 2007, almost half of whom, 383,107, lived in Palma, the capital (IBESTAT, 2008). That city was founded by the Romans, following invasion in 123 BC. This brought an urban civilization to a pre-urban island, which had its own endemic archaeological heritage, principally the early talayot settlement sites (Aramburu et al., 1998). Roman souvenirs may also be seen at the modern town of Alcudia wherein lies the Roman settlement of Pollentia with its ruins including a small amphitheatre (Doenges, 2005). Following the decline of the Roman Empire, Mallorca was taken by Vandals and Byzantines before falling to the Moors in the early $10^{\text {th }}$ century. Palma bears evidence of this, principally the surviving Arab baths and some elements of the Almudaina, a state building next to the magnificent Gothic cathedral. This latter structure is from the period of the Christian kings of Mallorca, the first of whom, Jaime I, took the island from the Moors in 1229. Mallorca remained an independent Christian kingdom until 1344 when it was incorporated into the holdings of the rulers of Aragon from the Spanish mainland. Another remembrance from the independent kingdom era is the series of eleven planned market towns in the interior, such as Sa Pobla (Mallorcan) / La Puebla (Castilian). These towns were established under King Jaime II in the $13^{\text {th }}$ century in an early expression of regional planning. They, and other towns which grew organically, are characterized by shuttered, stone buildings with red pantile roofs, which form an important element of the traditional townscape heritage on the island.

Palma was once walled and although most have been demolished, some stretches remain, particularly towards the sea. It has remains also of its traditional central high status compounds, substantial structures arranged around internal courtyards, which are hidden behind high walls to the street. George Sand (Aurore Dupin, Baroness Dudevant), the French author, was impressed by these buildings during her visit in 1838 :

"... after climbing the elegant staircase and penetrating into the house itself, you might be in a building dedicated solely to the siesta. Enormous rooms, usually rectangular in shape, very lofty, very cool, very dark" (Sand, 1855/1998: 41).

Like other Mediterranean cities, such as the better-known Barcelona, Palma boasts processional streets, ramblas, and many fine Art Nouveau buildings from the early $20^{\text {th }}$ century.

Mallorca's rural environment is also attractive: "this everywhere beautiful countryside" (Sand, 1855/1998: 117). The beaches may well have had to be extensively nourished to create/extend the necessary expanses of golden sands for modern tourists, but the natural landscape is fine, if subject, of course, to management problems (Crespi-Green, 2006). In particular, there is a spectacular mountain range, the Serra de Tramuntana, which stretches along the island's northwest coast, rising to $1445 \mathrm{~m}$ in Puig Major. These rugged mountains, like most of the rest of the island, are of limestone, a geology that has imposed water management problems worsened by a seasonal Mediterranean climate with limited 
summer precipitation which means that the island lacks permanent rivers and much of the water for agriculture has to be drawn from the water table. The wind pumps that used to perform this task formed a characteristic element of the rural scene. Groundwater is now raised by diesel or electric pumps, but some of the 'windmills' (as they are often incorrectly termed - they were not 'mills' but pumps) have been restored as heritage features. They sit amidst an intensive agricultural landscape in the central plain of the island where early potatoes, fruits, vegetables and cereals still present an active farming sector. Where water is less easily obtained and the soils less fertile, the island has tree crops, sometimes with a fodder crop beneath them. The trees are almonds, figs, carob and citrus fruit, with olives grown on higher ground. Viticulture is becoming increasingly important here as elsewhere in the Mediterranean (Lucas i Vidal, 2002). Especially in the areas under tree crops, Mallorca has characteristic dry-stone walls, the care of which is an important heritage concern.

\section{Historic Tourism}

Mallorca's first self-declared tourists, the 'explorers' of the Butler model, were George Sand, her two children and her companion, the Polish composer Frédéric Chopin, who all spent the winter of 1838-39 there. Thus wrote Sand when she finally published her account of the visit sixteen years later (1855/1998: 9):

"I find that I might have made myself as famous as the two Englishmen in the valley of Chamonix [who instigated tourism there] had I claimed the discovery of Majorca ... but since I felt far from enraptured while in Majorca I renounced my pioneering fame and recorded my discovery neither on granite nor on paper".

She had been captivated by the landscape: "one of the most beautiful places in the world, and one of the least explored" (1855/1998: 9), but was less enamored with the people, spending time "at daggers drawn with the wiliest peasants in the world" (1855/1998: 103). The issues included Chopin being ill throughout the visit, which raised concerns over infection. The couple did not attend mass, which caused further problems with the islanders, whilst "My daughter's loose jacket and trousers also offended local sentiment deeply. It was thought disgraceful that a 'young person' nine years of age should scour the mountains 'disguised as a man"” (1855/1998: 100).

Sand's Un Hiver à Majorque, today widely available on the island translated into the languages of her successor tourists, was remarkably prescient about Mallorca's tourism potential and also expressed awareness regarding what was wanting. This included a proper transport system: "if a direct steamer service were run from France to these regions, Majorca would soon prove a formidable rival to Switzerland ... The time will doubtless come when frail dilettantes and even lovely women will be able to visit Palma with no more exhaustion and discomfort than Geneva" (1855/1998: 10). Lack of accommodation was another problem: "Who would have guessed that in a country so close to civilized Europe, we should be unable to find a single inn?" (1855/1998: 24). Further, the local cuisine needed refinement: "Twenty dishes may appear on the table, all looking like every kind of Christmas food, but beware, they are hellish brews cooked by the Devil himself" 
(1855/1998: 101). However, she found Palma of interest and noted the potential of the attractive landscape: "Simple calm Majorca is a green Switzerland beneath a Calabrian sky, and with the silent solemnity of the Orient" (1855/1998: 10). She was also aware of the likely benefits of tourism to the islanders, though with a characteristically unpleasant dig at their character:

"Though he [the Mallorcan] would never rob his neighbour of so much as an olive, he believes that in God's scheme of things, the only use of human beings from overseas is to bring the Majorcans nice little profits" (1855/1998: 107).

During Sand's lifetime (1804-1876), foreign travel for enjoyment was an activity confined to the wealthy or at least the middle classes; working class tourism was almost exclusively limited to relatively local destinations, often nearby seaside resorts. The affluent travelers did not frequent Mallorca but tended to head to more significant classical locations in Italy and Greece (Morrison, 1953). Further, the Mediterranean littoral was troubled by malaria and this adversely affected the development of tourism there (Pemble, 1987). Mallorca's first properly-organized tourism, Butler's 'involvement', was not until the 1930s when cruise ships called at Palma and Porto Cristo, but the Spanish Civil War from 1936, followed by World War II from 1939, brought an end to leisure travel in the Mediterranean. What Sand could not have foreseen was that, when easy access was finally provided to her "green Switzerland", which occurred only sometime after the Second World War, rather than catering for her dilettantes it would bring tourists of an earthier character.

\section{Modern Tourism}

After the austerity period following World War II, mass tourism began to become a significant phenomenon in Europe. The increasingly affluent working-class populations from the north of the continent sought to holiday in sunnier climes than could be provided at Skegness or Sylt. Spain as a whole benefited from this trend, despite the contemporary political regime, thus the telling title of Sasha Pack's 2006 book, Tourism and Dictatorship: Europe's Peaceful Invasion of Franco's Spain. George Sand's requirement for adequate transport systems to island Spain came into play, not expressed by the steamers of her era, but by the development of commercial jet aircraft. This enabled relatively cheap, convenient flights to be made to the islands from northern Europe, just as to anywhere else in Spain and Mallorca became one of tourism's "mainland" islands as mentioned above, moving through Butler's 'development' and 'consolidation' stages.

Let us turn to another appropriate literary source written by an outsider for evidence of Mallorca in its new guise. This is Trim's Majorca Guide, an inexpensive paperback first written and published by Robert Trimnell in 1954. The character of the book might be seen in regard to what it has about geography, a subject to which Sand devoted an entire chapter in a reasonably scientific manner. By contrast, Trimnell simply stated that "this grim subject is easily disposed of" (1974: 4) and proceeded to do this with a simple map and 90 words on the road pattern, concluding "that's about all there is to Majorcan geography" (1974: 5). Rather, Trimnell assumed that his reader has arrived "bewildered" amidst the 
"milling crowd at the airport" (1974: 1) in need of advice on "where to get a good glass of beer, a real English cup of tea; dancing, sailing, drinking [and] which of the museums are worth your missing the sunshine" (1974: 3). The first, 'exploration', phase's problems with the delivery of tourists as identified by Sand have been solved. Those concerns Sand had over food had been sidestepped, as the new tourists were not eating Mallorcan cuisine: Trimnell's chapter on restaurants mentioned seven establishments, but for only one were island specialities highlighted. The issue over accommodation had been addressed by an active policy of encouraging coastal hotel building. Trimnell's 1974 edition, celebrating 20 years of publication, stated: "we knew Magaluf when there was only one small hotel there and not a chair on the beach. We have been the only people swimming at Illetas" and "sadly we watched the great concrete blocks of hotels and apartment houses going up all along the coast" (1974: facing inside front cover). As to the type of tourist in the concrete block hotels, Trimnell reflected their interests with two chapters on beaches, including revealing comments about clothing and the likelihood of sexual encounters. Mallorca was "the land of the Short Shorts. And girls" (1974: 11). Others chapters were entitled "Night Life", "Trim's Boozing Tips" and "Pub Hopping and Bar-Crawling" and would appeal to the type of tourist later to be described as a 'lager lout': "a young man who behaves in an aggressive, boorish manner as a result of drinking (typically lager) excessively" according to the Oxford English Dictionary, which dates the first use of the term to 1987.

\section{Resistance and Reaction}

Tourism has become responsible for $85 \%$ of Mallorca's GDP (Garín-Muñoza \& MonteroMartín, 2007) and the island has become wealthy. However, there have also been concerns that tourism-and also globalization and modernization-were damaging Mallorca's environment and cultural heritage. Matters became particularly acute because of the pressures on an island ecumene, as mentioned earlier. As early as the late-1980s, there were local protests against some tourist and other developments on environmental grounds. One interesting example was the campaign against plans for the use of Cabrera, an uninhabited islet off the south coast of Mallorca, by the Spanish defence ministry. There were massive demonstrations against this, led by the local NGO pressure group, GOB (formally the Grup Balear d'Ornitologia i Defensa de la Naturalesa), which was founded in 1973 and is still playing a crucial role in the preservation of the islands' environment (GOB, 2009). "Several thousand people at demo in defence of Cabrera" was a headline in the island's English-language newspaper, Majorca Daily Bulletin, on 18 March 1989. Cabrera and its archipelago, including the surrounding waters, were created a National Park in 1991 and now form part of a wider system of protected areas. Control of Cabrera National Park passed from the central Spanish government to that of the Balearic Islands in 2009. The agreement provided central funds to guarantee the park's environmental integrity whilst allowing limited and controlled public access via a visitor centre at the town of Colonia San Jordi. There were further protests in the early 1990s against land-use change in the form of encroachment onto undeveloped beach areas such as Es TrencSalvem Es Trenc screamed a graffito on a wall photographed by the author. Actual and potential developments at the Albufera wetland and heathland areas such as that behind the prehistoric necropolis of Son Real on the beach near the German-dominated resort of Ca'n Picafort also raised concerns. 
Concerns over the environment were matched by those over the impacts of tourism on culture. Orvar Löfgren (1999) has opined that, generally, most modern vacations do not involve meaningful cultural exchange. This can be seen on Mallorca, even in situations where relatively sophisticated visitors are involved, such as those attracted to the picturesque mountain village of Deià, noted for its association with the English poet, Robert Graves. Jacqueline Waldren (1996) found that whilst foreign investment had brought material benefits for Deià's villagers, symbolic boundaries remained between the Insiders and outsiders of her title regarding social relations and cultural practices, just as they had in the days of George Sand, our original outsider. Regarding the mass-market tourists, few would have any interest in interacting with local people or their culture. To many of them, drinking San Miguel beer (itself from mainland Spain rather than Mallorca) would be the only concession made to their being in a foreign location. Their resorts tend to be dominated by particular national groups and cater for them with familiar foodstuffs. Bratwurst is available in German-dominated areas; those catering for the British and Irish serve burgers; only a few of the author's more adventurous students have ever been observed eating foods they would not immediately have recognized from home. Communication in the resorts' restaurants and bars inevitably takes place in the tourists' languages; most local people working in hospitality have at least adequate English and/or German. Having to serve bland North European food to unadventurous tourists in their language is of some concern regarding the purity and long-term survival of local culture. However, at least the tourism workers can go home and speak the local language and there are restaurants and other places where usually only locals or knowledgeable resident foreigners go. In such establishments few concessions are made to outsiders in terms of providing familiar foods or language. The Celler Sa Premsa in Palma might appear be one such example. A large restaurant, which opened in 1958 a few streets away from the main tourist area, in its traditional surrounds with walls covered with bull-fighting posters it serves inexpensive Mallorcan wine and food, selected from a menu printed only in the local language. It does, however, maintain a website with pages in English and German (Celler Sa Premsa, 2009) and some locals condemn it as a commodified tourist haunt.

Of greater concern is the impact on culture of retirees and second-home owners who live on the island for at least substantial periods of the year (see O'Reilly, 2000; King et al., 2000, for mainland Spanish and Mediterranean studies of this phenomenon). Many such people inhabit purpose-built accommodation, but others compete in the open market against the Spanish and Mallorcans, particularly since the accession of Spain into the European Union in 1986, which facilitated the purchase of Spanish property by people from other EU countries. Their presence in the market restricts the opportunities of local people for buying property. Further, few of these migrants have attempted to integrate; most continue to live their lives through English or German. There have long been foreignlanguage local newspapers such as the German Mallorca Magazin and Majorca Daily Bulletin, which was first published in 1962. Furthermore, modern communications mean that access to television and other entertainment in foreign languages is easy to arrange. As long ago as 1999, there was a headline: "Cultural body worried at lack of German integration" (Majorca Daily Bulletin, 4 April 1999), with a report that the Balearic cultural body, Obra Cultural Balear (OCB), found it "shocking" and "detrimental to the continuation of the Balearics very unique culture" that " $68 \%$ of German residents do not 
speak either Spanish or Catalan, the two official languages of the islands, $40 \%$ of those questioned said they had no interest in learning them or anything about the local culture, whilst more than half expressed that they do not feel integrated into the local community".

Cultural heritage matters are complicated on Mallorca by contestation between Castilianspeaking Spaniards and the locals. There is resentment at leakage from the tourism industry, at what is seen as foreign (including Spanish) profiteering. The language issue has been expressed in matters such as road signs. The author has pictures of Castilian place names on the signs being altered to Mallorcan-Santa Margarita to Santa Margalida - then the official signs being changed into Mallorcan, only for a Castilian speaker to use paint to change the new sign back - Santa Margalida to Santa Margarita. Another graffito read "Mallorca per els Mallorquin": Mallorca for the Mallorcans. There are political parties in the Balearics pressing for independence, but without violence, unlike on the contested French-ruled Mediterranean island of Corsica with the FLNC, (although in the summer of 2009 ETA, the mainland Basque separatist group, exploded bombs on Mallorca, killing two police officers). Any political, inter-communal strife is a distraction from social and economic advance and this has added to the other causes of unease on the island.

By the 1990s matters had come to a head. In addition to the environmental, heritage and cultural concerns about the impacts of mass tourism, there were worries about the tourism industry itself. Figure 3 which is a time series of passenger movements through Palma airport from 1982 to 2008, shows that, in the late 1980s and early 1990s, numbers had ceased to rise. The pleasure periphery principle (Turner \& Ash, 1975) seemed to be taking some potential tourists beyond Mallorca to newer, more distant and more fashionable locations and the Butler model might be seen to have reached the point of "stagnation" for Mallorca. All things pointed to the need to re-launch Mallorca's tourism product in a new direction (see also Bardolet, 2001).

Figure 3 - Passenger arrivals and departures, Palma airport, 1982-2008 Source: Drawn from data in CITTIB (2008).

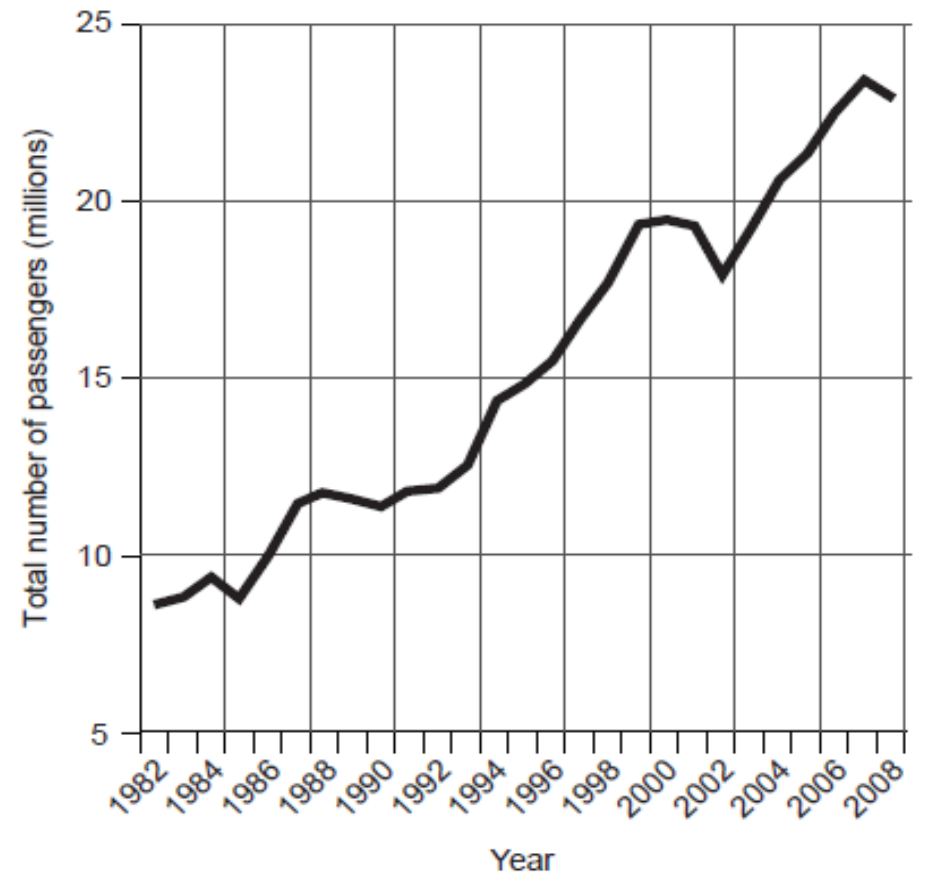

Local Agenda 21

Another catalyst for action seems to have been the United Nations Conference on Environment and Development (better known as the Earth Summit) held in Rio de Janeiro in 1992. Especially with its generation of Local Agenda 21, this provided a framework for implementing sustainable development at the local level, supported in Europe by the First European Conference of 
Sustainable Cities and Towns, organized in 1994 at Aalborg in Denmark (Garcia-Sanchez \& Prado-Lorenzo, 2008). Let us take the example of Calvià, a $143 \mathrm{~km}^{2}$ district with $60 \mathrm{~km}$ of coast in southwest Mallorca containing many major resorts including Magaluf, Illetas, Palma Nova, Santa Ponsa and Peguera. Here "Local Agenda 21 is the articulation of the local philosophy, strategy and plan of action to recover from the over-building and environmental destruction of the last two decades, and to guide the tourist sector in the next decades towards new formulas whose common denominator is sustainability" (Calvià City Council, n.d.: 1). Calvià produced a comprehensive plan of action under Local Agenda 21, detailed in a book describing ten "lines of action" and forty initiatives (Ajuntament de Calvià, 1998). The council's embrace of the agenda has had direct impacts on land-use. Some coastal concrete block hotels, those that were "obsolete and offensive to the environment" and whose erection caused sadness to Trim have been demolished, whilst new regard has been paid to carrying capacity in tourism development according to the undated council report seen by the author (Calvià, n.d.). The promenades have been remodelled to "protect sensitive areas", new zona verde (green areas) have been inserted into the townscape, water control and pollution measures have been imposed on new constructions. The report claims that the adoption of Local Agenda 21 has led to positive outcomes not only environmentally, but also socially, whilst with regard to the economy, the improvement of the "touristic quality of life" has been of benefit. There was some opposition, the Council reported, especially from builders and developers who saw their businesses as being endangered by re-zoning of some land to new categories that prevented construction. Some major projects continue within Calvià and, at the time of writing, the small cove at Penyes Rotges (Port Adriano) is being transformed. There is an extensive new harbour facility under construction to accommodate the largest categories of tourist boats. More significantly, perhaps, the cliff sections here that are amongst the most significant natural sites in the island given the detail they reveal about environmental history such as sea level change, are being armoured to protect new developments on the cliff top at the cost of concealing the geomorphological record.

\section{Protection and 'Rejuvenation'}

Losses such as the cliff sections at Penyes Rotges are rarer now than they once were. In recent years environmental protection legislation has been enacted in Mallorca and there are now National Parks, Natural Reserves and Parks, Special and Integral Nature Reserves and Natural Monuments, which together protect just under $15 \%$ of the total land area (IBESTAT, 2008). Other small areas are held as Finca Pública (Public Estate). Marine reserves of various sorts, including the National Park around Cabrera have also been declared. NGOs such as OCB, GOB and the Foundation for The Sustainable Tourism of the Balearic Islands keep a watching brief on developments. More could be done, doubtless: the necropolis at Son Real, though categorized as Finca Pública, is 'protected' only by a multi-lingual sign asking in vain in Mallorcan, Spanish, German and English for people to stay off the tombs. One failure operating at the island scale was a short-lived scheme to charge each tourist a tax of $€ 2$ a day to provide a fund to be used for environmental protection. This was subject to protests from foreign newspapers, particularly in Germany, who involved the King of Spain in the matter: "Majestät, stoppen 
Sie diessen Unsinn" (Your Majesty, halt this madness) was the headline in the popular German daily, Bild, on 18 April 2001, over an article which urged its readers to write to the king, protesting against the ecotax. It operated for little over a year before being dropped. However, an ecological pressure group, Mallorca Goes Green, revived the idea in 2009 , suggesting that it should be applied to all visitors, not just hotel and apartment guests as before (Mallorca Goes Green, 2009).

Regarding the built heritage, two examples might be given of recent changes in attitude. The Roman site of Pollentia used to be completely open, back in the 1980s the author once observed young foreigners throwing stones plucked from the 2000-year-old walls of its ruined buildings. Today, all is fenced off and protected, the site accessible only after purchasing a ticket and, presumably, stone throwing would not be tolerated. In Palma, the Almudaina and cathedral were always cherished, of course; but there is new regard shown to what is left of the old city walls. These were largely demolished in 1902, but some sections remained, particularly towards the coast. These have been carefully restored in a recent project adorned with signs saying "Recuperam la murada per a Ciutat" (Recovering the walls for the city). The southwest corner has been turned into a cultural showcase with a museum of modern art, Esballuard, which was opened by the King of Spain in 2004. There is also an up-market restaurant and displays of sculpture.

Another aspect of Mallorca's transformation has been that common policy of modern tourism campaigns across the globe, eco-tourism (Lück \& Kirstges, 2003). Encouraging eco-tourism on Mallorca has had the bonus of attracting a different market sector from the lager lout, a group that would tend to be more affluent and likely to spend more per head, a benefit to the locals' "nice little profits" to repeat Sand's characterization. The author has a collection of advertising material published since Calvià's tourism re-launch, which emphasises forests, wildlife, walking, golf and cycling. One flyer features an attractive, white-haired couple seen enjoying their time on the island by indulging in such activities and, whilst there is both a beach scene and a photograph of them dancing, on the beach they are performing aerobics rather than lying comatose and for the dance they have donned evening dress; a different market sector indeed.

Official statistics confirm that passenger numbers and associated occupancy rates have increased in recent years after the flat period in the late-1980s. Figure 3 shows dips in arrivals only after the 9/11 attacks in New York and Washington in 2001 and a downturn from 2007 to 2008 associated with the recession. Aguiló et al confirm that this regained growth is associated with the new policy:

"The high indices of occupation in recent years in all the areas of the Balearic Islands are not the fruit of a drop in prices, but rather, among other factors, of a rise in the quality of the product which goes hand in hand with a moderate increase in prices" (2002: 20-21).

Visitor numbers and income associated with tourists outside the mass-market are rising: total annual income to the Balearic Islands from golf tourists rose from $€ 198 \mathrm{~m}$ to $€ 234 \mathrm{~m}$ between 2003 and 2008; that from cycle tourists moved from $€ 71 \mathrm{~m}$ to $€ 92 \mathrm{~m}$ for the same 
period (CITTIB, 2008). Further evidence can be seen from a comparison of mean daily spend across Spanish tourism regions (Table 1), which shows that, whilst expensive Madrid tops the list by a considerable margin, Mallorca and the rest of the Balearic Islands have a higher daily spend than competitor costas on the Spanish mainland.

Table 1 - Mean daily spend (Euro), non-resident tourists to Spain, 2005.

\begin{tabular}{|c|c|}
\hline Madrid & $€ 135$ \\
\hline Canary Islands & $€ 95$ \\
\hline Balearic Islands & $€ 90$ \\
\hline Catalonia & $€ 82$ \\
\hline Andalucia & $€ 80$ \\
\hline Others & $€ 78$ \\
\hline Valencia & $€ 64$ \\
\hline
\end{tabular}

Source: Ministerio de Industria, Turismo y Commercio (2005).

All has not changed in that mass tourism still exists in Mallorca. On his 2009 field trip, the author observed a board outside a café in Palma Nova which trumpeted that, whilst watching English soccer matches on television, patrons could enjoy that British contribution to world cuisine, the all day breakfast, with "proper bacon", Heinz beans (a popular brand back home) and black pudding. However, the mass-market is not what it was: "Your hols will Costa packet", screamed a characteristically punning headline in the irrepressible, down-market British tabloid newspaper, The Sun, on 28 May 2008. If fewer Sun readers can afford to travel for their fortnight's holiday to the island, Mallorca refining its tourism product for the higher end of the market could prove to be of economic merit as well as benefiting the environment, heritage and culture.

\section{Conclusion}

This paper took Mallorca as an example of a 'mainland' island in tourism terms and showed that its history of tourism conformed broadly to the generalities of the Butler model. However, what can be recognised as the 'rejuvenation' phase was a response to a wide range of internal needs, including the necessity of protecting heritage and culture from the depredations of mass tourism, as much as to concerns about falling numbers of visitors. External stimuli, including Local Agenda 21, also exerted influence. That the rejuvenation was a complex matter might be ascribed at least partly to factors imposed by insularity, particularly the bounded nature of the small island ecumene as described. Another issue could be the small-scale nature of an island society, which renders it vulnerable to being overwhelmed by visitors with different languages and cultural norms. The author recalls walking with his students through one of Mallorca's inland towns away from the tourist areas when a passing local woman placed her hand over the eyes of her grandson to shield him from the sight of the young northern European women in their shorts: shades of the boundaries between Waldren's insiders and outsiders. Perhaps it is 
not a matter of surprise that the Mallorcan people, although having benefited tremendously from tourism in economic terms, should have favoured some elements of control of the industry.

Counterparts to 'mainland' islands - as identified in the introduction - are places identified as 'entry' islands. By the very use of such a term these islands cannot have progressed far along Butler's tourist area journey. Some, such as the Falkland Islands, may always have had a different destination anyway, being 'cold-water' islands (Royle, 2006), unlikely ever to attract the large numbers of tourists expected by the later stages of Butler's model. Others in sunnier climes might have more potential but in the nearly 30 years since the appearance of Butler's model, knowledge of the problems tourism can bring to islands has become widely recognized - exemplified neatly by the telling exclamation mark in Sheere Brooks's (2008) chapter title: "“A squatter in my own country!" Spatial manifestations of social exclusion in a Jamaican resort town'. The policy makers of the 'entry' islands will now have an awareness of the potential depredations of tourism and may not permit development of the industry to full mass-market conditions. With regard to the particular cases of small islands perhaps Butler's model is now of greater utility in explaining what happened in the past to mature, 'mainland' island tourist destinations rather than in predicting what will happen to the 'entry' islands in the future.

\section{Acknowledgements}

Thanks are due to the generations of students who have accompanied me to Mallorca and to the anonymous reviewers of earlier versions of this article.

\section{References}

Aguiló, E., Alegre, J. \& Sard, M. (2002) The Analysis of Tourist Demand as a Criteria in Destination Positioning. The Persistence of the Sun and Beach Tourist Model in the Balearic Islands, Palma de Mallorca, Universitat de Illes Balears Dept de Economia i Empresa.

Ajuntament de Calvià, (1998) Calvià Local Agenda 21, The Sustainability of a Tourist Municipality Plan of Action, Calvià, Ajuntament de Calvià.

Aramburu, J., Garrido, C. \& Sastre, V. (1998) Guía Arqueológica de Mallorca, $3^{\text {rd }}$ Edition, Palma de Mallorca, Collección Foradada.

Bardolet, E. (2001) 'The Path Towards Sustainability in the Balearic Islands' in D. Ioannides, Y. Apostolopoulos \& S. Sonmez (eds.) Mediterranean Islands and Sustainable Tourism Development: Practices, Management and Policies, London, Continuum, pp. 193-213.

Bartlett, M.W. (2007) Cyprus, the United Nations and the Quest for Unity, Ely, Melrose Books. 
Bradford, E.D.S. (1999) The Great Siege: Malta 1565, Ware, Wordsworth Editions.

Brooks, S. (2008) “"A Squatter in My Own Country!” Spatial Manifestations of Social Exclusion in a Jamaican Resort Town', in M. Daye, D. Chambers \& S. Roberts (eds.) New Perspectives in Caribbean Tourism, London, Routledge, pp. 163-187.

Butler, R.W. (1980), 'The Concept of a Tourist Area Cycle of Evolution: Implications for Management of Resources', Canadian Geographer, Vol. 24, No. 1, pp. 5-12.

Butler, R.W. (2003) 'Modelling Tourism Development: Evolution, Growth and Decline' in S. Williams (ed), Tourism: Development and Sustainability, Volume 3 of Tourism: Critical Concepts in the Social Sciences, London, Routledge, pp. 124-140.

Calvià City Council (n.d.) Calvià Local Agenda 21: Sustainable Development in Ageing Resort Areas, Calvià, Spain, Calvià City Council.

Connell, J. \& King, R. (1999) 'Island Migration in a Changing World' in R. King \& J. Connell (eds.) Small Worlds, Global Lives: Islands and Migration, London, Pinter, pp. 126.

Crespi-Green, V. (2006) Landscapes of Mallorca: A Countryside Guide, $6^{\text {th }}$ Edition, London, Sunflower Books.

Celler Sa Premsa (2009) http://www.cellersapremsa.com/en/presentacion.htm.

CITTIB (2008) El Turisme a les Illes Balears: Dades Informatives 2008, Palma, Conselleria de Turisme.

Doenges, N.A. (2005) Pollentia: A Roman Colony on the Island of Mallorca, Oxford, Archaeopress.

Forty, G. (2001) The Battle of Crete, Hersham, Ian Allan.

Garcia-Sanchez, I.M. \& Prado-Lorenzo, J-M. (2008) 'Determinant Factors in the Degree of Implementation of Local Agenda 21 in the European Union', Sustainable Development, Vol. 16, No. 1, pp. 17-34.

Garín-Muñoza, T. \& Montero-Martín, L.F. (2007) 'Tourism in the Balearic Islands: A Dynamic Model for International Demand Using Panel Data', Tourism Management, Vol. 28, No. 2, pp. 1224-1235.

GOB (2009) http://www.gobmallorca.com/.

IBESTAT (Institut d'Estadística de les Illes Balears) (2008) Les Illes Balears en Xifres, 2008, Palma, IBESTAT. 
Jansen, M.E. (2005) War and Cultural Heritage: Cyprus after the 1974 Turkish Invasion, Minneapolis MN, University of Minnesota Press.

King, R., Warnes, A.M. \& Williams, A.M. (2000) Sunset Lives: British Retirement Migration to the Mediterranean, Oxford, Berg.

Lecouer, S. (2008) Mussolini's Greek Island: Famine and the Italian Occupation of Syros in World War II, London, IB Tauris.

Löfgren, O. (1999) On Holiday: A History of Vacationing, London, University of California Press.

Lucas i Vidal, A.M. (2002) Les Activitats Agràries, Pesqueres i Forestals a les Illes Balears, Palma de Mallorca, Govern de les Illes Balears Conselleria d'Agricultura i Pesca.

Lück, M. \& Kirstges, T. (eds.) (2003) Global Ecotourism Policies and Case Studies: Perspectives and Constraints, Clevedon, Channel View Publications.

Mallorca Goes Green (2009) www.Mallorcagoesgreen.org.

Ministerio de Industria, Turismo y Commercio (2006) Assessment of Tourism in Spain in 2005, Madrid, Ministerio de Industria, Turismo y Commercio.

Morrison, H.B. (ed.) (1953) The Golden Age of Travel: Literary Impressions of the Grand Tour, London, Melrose.

Oliver, R.L. (1942) Malta at Bay: An Eye-Witness Account, London, Hutchinson.

O'Reilly, K. (2000) British on the Costa del Sol, London, Routledge.

Pack, S.D. (2006) Tourism and Dictatorship: Europe's Peaceful Invasion of Franco's Spain, Basingstoke, Palgrave Macmillan.

Pemble, John (1987) The Mediterranean Passion: Victorians and Edwardians in the South, Oxford, Oxford University Press.

Royle, S.A. (2006) 'The Falkland Islands', in G. Baldacchino (ed.) Extreme Tourism: Lessons from the World's Cold Water Islands, Elsevier, Oxford, pp. 81-192.

Royle, S.A. (2008) "“Mainland" and "Entry" Islands: Distinctions in Island Tourism' in S. Babu, B.B. Parida \& S. Mishra (eds.) Tourism Business: Some Reflections on a Changing Paradigm, New Delhi, Response Books, pp. 120-131. 
Sand, G. (1855/1998) Winter in Majorca, forward and translation by R. Graves, Palma de Mallorca, Collección Foradada.

Trimnell, R.L. (1974) Trim's Majorca Guide, $20^{\text {th }}$ edition, Palma de Mallorca, Trimnell.

Turner, L. \& Ash, J. (1975) The Golden Hordes: International Tourism and the Pleasure Periphery, London, Constable.

Waldren, J. (1996) Insiders and Outsiders: Paradise and Reality in Mallorca, Oxford, Berghahn Books. 